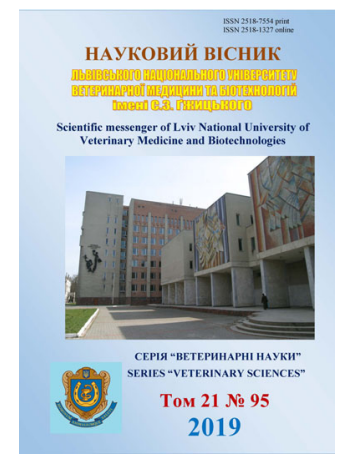

\author{
Науковий вісник Дьвівського національного університету \\ ветеринарної медицини та біотехнологій імені С.3. Гжицького. \\ Серія: Ветеринарні науки \\ Scientific Messenger of Lviv National University \\ of Veterinary Medicine and Biotechnologies. \\ Series: Veterinary sciences
}

UDC 619:614.31: 636.084.3

\title{
Sanitary and microbiological indicators of drinking water of livestock farms
}

\author{
T.I. Fotina, S.M. Nazarenko, A.I. Fotin \\ Sumy National Agrarian University, Sumy, Ukraine
}

Article info

Received 18.09.2019 Received in revised form 17.10.2019

Accepted 18.10.2019

Sumy National Agrarian University, G. Kondrat'eva Str., 160, Sumy, 40000, Ukraine.

Tel.:+38-095-495-29-33

E-mail: tif_ua@meta.ua
Fotina, T.I., Nazarenko, S.M., \& Fotin, A.I. (2019). Sanitary and microbiological indicators of drinking water of livestock farms. Scientific Messenger of Lviv National University of Veterinary Medicine and Biotechnologies. Series: Veterinary sciences, 21(95), 112-116. doi: $10.32718 /$ nvlvet 9521

The article presents data on the study of sanitary and microbiological indicators of drinking water of livestock farms. The criteria for sanitary and hygienic assessment of water from a microbiological point of view are the total amount of microflora and the presence or absence of Escherichia coli, the definition of pathogenic microorganisms, including salmonella, which characterize its fitness for consumption by animals. The main purpose of sanitary and microbiological research is to provide animals, the population with quality water, for which hygienic assessment of water of infectious safety for human and animal health is carried out. Full supply of livestock enterprises with good quality water is one of the main prerequisites for successful production of quality and safe livestock products. The goal of the work. In connection with this, the purpose of our research was to investigate the sanitary and microbiological parameters of the drinking water of livestock farms. Sanitary and microbiological studies of drinking water sources for animals were conducted. It was found that in the studied samples, the number of bacteria of the group of Escherichia coli $(B G K P)$ in 1 liter of water (coli-index) ranges from 200 to 140000 and more. Of all the samples tested for this indicator, only $39.4 \%$ of the reservoirs met the normative indicator. Water samples from artesian wells in $12.3 \%$ of cases did not meet the sanitary and hygienic requirements for the amount of BGKP. When carrying out sanitary-microbiological analysis of samples of water from various elements of water supply systems with respect to conditionally pathogenic microflora, it was found that the samples that were collected from the wafers had the highest degree of microbial contamination. The total number of microorganisms was $10^{7} \mathrm{CFU} / \mathrm{cm}^{3}$, and the coli index exceeded 240 thousand units. Examining the water samples found that $40 \%$ of the samples had an increased amount of enterobacteria. From the samples tested, 100 cultures of conditionally pathogenic microflora were isolated, including E. faecalis - 32\%, E. coli-23\%, E. cloacae$9 \%$, E. faecium - $11 \%$ and K. pneumoniae - 4\%, of which 59.3 respectively: 30.4; 33.3; 54.5 and $75 \%$ had hemolytic properties. E. faecalis showed resistance to erythromycin, cefuroxime, benzylpenicillin, ampicillin, tetracycline, vancomycin; E. faecium - to vancomycin, ciprofloxacin, tetracycline; representatives of the family Enterobacteriacea (E. coli, K. pneumoniae, E. cloacae) - mainly to amoxicillin, streptomycin, levomycetin.

Key words: livestock farms, drinking water, sanitary and microbiological parameters, microorganisms.

\section{Санітарно-мікробіологічні показники питної води тваринницьких ферм}

\author{
T.I. Фотіна, C.M. Назаренко, А.І. Фотін
}

Сумський національний аграрний університет, м. Суми, Украӥна

У статті наведені дані щзодо дослідження санітарно-мікробіологічних показників питної води тваринницьких ферм. Критеріями санітарно-гігієнічної оцінки води з мікробіологічного погляду є загальна кількість мікрофлори і наявність або відсутність у ній кишкової палички, визначення патогенних мікроорганізмів, у тому числі сальмонел, шуо характеризують ї̈ придатність до споживання тваринами. Основною метою санітарно-мікробіологічного дослідження є забезпечення тварин якісною водою, для чого проводиться гігієнічне очінювання води щзоо інфекиійної безпеки для здоров'я людей і тварин. Повне забезпечення тваринни- 
изких підприємств доброякісною водою в достатній кількості - одна з основних передумов успішного виробництва якісної та безпечної продукиї тваринництва. В зв'язку з ичим метою наших досліджень було дослідження санітарно-мікробіологічних показників питної води тваринницьких ферм. Було проведено санітарно-мікробіологічні дослідження джерел питної води для тварин. При цьому встановлено, щуо у досліджуваних пробах кількість бактерій групи кишкової палички (БГКП) в 1 л води (колі-індекс) коливається від 200 до 140000 та більше. Зі всіх досліджених проб за даним показником нормативному показнику відповідало тільки 39,4\% водоймищ. Проби води із артезіанських свердловин в 12,3\% випадків не відповідали санітарно-гігієнічним вимогам за кількістю БГКП. При проведенні санітарно-мікробіологічного аналізу проб води з різних елементів систем водопостачання щзодо умовно-патогенної мікрофлори встановили, щь найвищий ступінь мікробної контамінацї мали проби, які було відібрано з напувалок. Загальна кількість мікроорганізмів склала $10^{7} \mathrm{KУO} / \mathrm{cm}^{3}$, а колі-індекс перевищував 240 тис. одиниць. Дослідивщи проби води, встановили, щзо 40\% зразків мали підвищену кількість ентеробактерій. Із підданих дослідженню проб води виділили 100 культур умовно-патогенної мікрофлори, в тому числі E. faecalis - 32\%, E. coli-23\%, E. cloacae - 9\%, E. faecium-11\% i K. pneumoniae - 4\%, із них відповідно 59,3; 30,4; 33,3; 54,5 і 75\% були притаманні гемолітичні властивості. E. faесаlis виявили стійкість до еритроміцинн, цефуроксиму, бензилпеніциліну, ампіциліну, тетрацикліну, ванкоміцину; Е. ғаесіит - до ванкоміцину, цчипрофлоксацину, тетрацикліну; представники родини Enterobacteriacea (E. coli, K. рпеитопіае, E. сlоасае) - переважно до амоксициліну, стрептоміцину, левоміцетину.

Ключові слова: тваринницькі ферми, питна вода, санітарно-мікробіологічні показники, мікроорганізми.

\section{Вступ}

Вода належить до природних середовищ, в яких існують мікроорганізми. У воді річок, відкритих водоймищ, морів, океанів виявляють представників усіх таксономічних груп: скотобактерії, фотобактерії, архібактерії, найпростіші, гриби, водорості. Мікрофлора водоймищ визначається особливостями певного водного середовища, оскільки різні водні мікроорганізми мають потребу в різних умовах існування. Мікроорганізми, що пристосувалися до умов існування у воді та постійно перебувають у ній, можна вважати специфічною для води флорою. До них належать аеробні коки і бактерії (Micrococcus candicans, Micrococcus roseus, Sarcina lutea, бактерії: Bacterium aquatilis communis, Pseudomonas fluorencens. Роду Proteus; представники роду Leptospira. Вміст анаеробних бактерій у чистих незабруднених водоймищах незначний. Найчастіше виявляються Serratia marsescens, Bacillus cereus, Bacillus mycoides, мікроорганізми роду Clostridium та ін. Кількісні співвідношення мікроорганізмів у воді відкритих водоймищ коливається в широких межах: від декількох десятків, сотень до мільйонів в 1 мл, що залежить від виду водоймища, ступеня його забруднення, зміни метеорологічних умов, пори року (Holovko \& Rublenko, 2010).

Основною метою санітарно-мікробіологічного дослідження є забезпечення тварин, населення якісною водою, для чого проводиться гігієнічне оцінювання води щодо інфекційної безпеки для здоров'я людей і тварин.

Повне забезпечення тваринницьких підприємств доброякісною водою в достатній кількості - одна 3 основних передумов успішного виробництва якісної та безпечної продукції тваринництва.

Основними критеріями санітарно-гігієнічної оцінки води з мікробіологічного погляду є загальна кількість мікрофлори і наявність або відсутність у ній кишкової палички, визначення патогенних мікроорганізмів, у тому числі сальмонел, що характеризують їі придатність до споживання тваринами (Zapolskyi, 2005).

На рівень бактеріальної забрудненості води, яка використовується для напування тварин, впливають: якість води джерела, рівень чистоти водопровідних систем (“мертві зони”), повільна циркуляція води, введення медикаментів або кормових добавок на органічних носіях, висока температура, потрапляння мікроорганізмів через клапан напувалок у систему та їх швидке розмноження, незадовільне очищення напувалок тощо (Laptiev, 2012; Vajsburd, 2014; Andrushchuk, 2015).

Використання неякісної води спричиняє підвищення захворюваності тварин.

Велику роль у забрудненні води у сільській місцевості відіграють тваринницькі підприємства та інші об'єкти ветеринарно-санітарного нагляду (Zasiekin et al., 2009; Karas', 2009). Найрозповсюдженішим є хімічне, мікробіологічне та радіоактивне забруднення.

На сьогодні встановлено, що небезпека захворювань від наявних у воді патогенних мікроорганізмів $\epsilon$ в декілька разів вищою, ніж при забрудненні води хімічними сполуками. Особливо небезпечними є збудники лептоспірозу, сальмонельозу, туляремії, сибірки, ентеро- та аденовірусів. Багатьма науковцями досліджено та підтверджено, що збудники кишкових інфекцій можуть передаватися через недостатньо чи неякісно знезаражену воду. Тому використання води, забрудненої цими збудниками, може призвести до виникнення епідеміологічних спалахів (Glasgow et al., 2004; Helbling \& VanBriesen, 2009; Gómez et al., 2011).

У тваринництві рідко проводять оцінку якості води, хоча є твердження авторів (Hirol \& Kovalskyi, 2008; Sokoliuk et al., 2011) про іiі забруднення і ризики захворювання тварин, птиці та зниження їхньої продуктивності.

Деякі дослідження свідчать про високу мікробіологічну чистоту води в місці ії забору, але в більшості випадків спеціалісти зауважують іiї зниження у водопроводі та напувалках. Так, середній рівень бактеріального обсіменіння ніпельної напувалки був в 20 разів нижчий, ніж у чашковій (Zasiekin et al., 2009; Vajsburd, 2014; Dong et al., 2015).

Найчастіше вода забруднюється безпосередньо в поїлках, особливо відкритого типу. Розповсюдження патогенної мікрофлори проходить шляхом “зворотного росту" - через клапан поїлки всередину системи водопостачання. 
Тому важливе місце у запобіганні інфекційним хворобам займає контроль за якістю та безпечністю питної води, яку оцінюють за мікробіологічними показниками, зокрема - загальним мікробним забрудненням та відсутністю патогенних мікроорганізмів. Чим вищий показник мікробного забруднення води, тим важче іiї знезаразити та більша ймовірність інфікування макроорганізму (Hirol \& Kovalskyi, 2008).

Крім того, наявність Escherichia coli, Staphylococcus spp., Pseudomonas aeruginosa може вказувати на неякісне водопостачання і забруднення води, що створює умови для розвитку і поширення шлунково-кишкових захворювань. Тому саме контроль якості води має вплив як на покращення виробничих процесів, так і на зниження захворювання тварин.

Мета і завдання дослідження. У зв'язку з цим метою досліджень було визначити санітарномікробіологічні показники питної води тваринницьких ферм. Для досягнення поставленої мети необхідно було вирішити такі завдання:

1. Провести санітарно-мікробіологічні дослідження питної води для тварин.

2. Встановити гемолітичні та антибіотикорезистентні властивості умовно-патогенної мікрофлори.

3. Надати пропозиції з урахуванням отриманих результатів про перспективи використання економічно доцільних методів корекції санітарномікробіологічних показників води.

\section{Матеріал і методи дослідження}

Робота виконувалася на базі лабораторії "Інноваційні технології та безпеки і якості продуктів тваринництва" та "Ветеринарна фармація" кафедри ветсанекспертизи, мікробіології, зоогігієни та безпеки і якості продуктів тваринництва факультету ветеринарної медицини Сумського національного аграрного університету та фермерських господарствах Сумської області.

Санітарно-мікробіологічні показники питної води проводили на 12 фермах Сумської області. Було відібрано 126 проб води 3 природних водойм, свердловин, водопровідних мереж ферм, резервуарів і поїлок для тварин, що досліджували бактеріологічними загальноприйнятими методами. Визначення загального мікробного забруднення (мікробного числа) води і колііндексу, проводили згідно з ДСанПіН 2.2.4-171-10 (Hihiienichni vymohy..., 2011).

Із 2-х різних розведень дослідної проби у кількості 1 мл вносили у 2 бактеріологічні чашки і заливали 15 мл розплавленого і охолодженого до $45^{\circ} \mathrm{C}$ МПА проби культивували за t $37^{\circ} \mathrm{C}$.

Загальну кількість мікроорганізмів у 1 мл визначали методом підрахунку колоній, що виросли за кожного розведення та множили кількість колоній на ступінь розведення і підраховували їхню кількість.

Колі-індекс визначали методом мембранних фільтрувань згідно з ДС 18963-73. Для фільтрування ви- користовували нітроцелюлозний фільтр № 2, через який проби води пропускали об ємом 500 мл, воду із напувалок розводили у співвідношення 1:100 і проводили фільтрування. Після фільтрації фільтр за допомогою пінцета поміщали на середовище Левіна та Ендо у чашках Петрі. Культивування проводили 24 годин за t $37{ }^{\circ} \mathrm{C}$. Колі-індекс визначали шляхом підрахунку кількість колоній, типових для кишкової палички.

Загальне мікробне обсіменіння визначали у 1 мл води методом посіву на тверді живильні середовища із проб, приготовлених за методом серійних розведень, згідно з ДСТУ ISO 4833-2006.

\section{Результати та їх обговорення}

Було проведено санітарно-мікробіологічні дослідження джерел питної води для тварин. При цьому встановлено, що у досліджуваних пробах кількість бактерій групи кишкової палички (БГКП) в 1 л води (колі-індекс) коливається від 200 до 140000 та більше. Зі всіх досліджених проб за даним показником нормативному показнику відповідало тільки 39,4\% водоймищ. Проби води із артезіанських свердловин в 12,3\% випадків не відповідали санітарно-гігієнічним вимогам за кількістю БГКП.

При проведенні санітарно-мікробіологічного аналізу проб води з різних елементів систем водопостачання щодо умовно-патогенної мікрофлори встановили, що найбільш високий ступінь мікробної контамінації мали проби, які було відібрано 3 напувалок. Загальна кількість мікроорганізмів склала $10^{7} \mathrm{KУО} / \mathrm{cm}^{3}$, а колі-індекс перевищував 240 тис. одиниць.

Дослідивши проби води, встановили, що 40\% зразків мали підвищену кількість ентеробактерій.

Доведено, що у 28-100\% випадках проби води не відповідали санітарно-гігієнічним вимогам. В 39,1\% випадків було ізольовано E. coli, із загальної кількості яких 59,6\% мали ентеропатогенні властивості. При дослідженні води на наявність санітарно-показових мікроорганізмів (які непрямо вказують на можливість забруднення води патогенними мікроорганізмами) було виділено кишкову паличку (рис.1). На середовищі Левіна виділено збудника - колонії темнофіолетового кольору, на Ендо - колонії малинового кольору з металевим блиском; спостерігали зміну кольору середовища з блідо-рожевого на малиновий, що було характерно для E. coli.

Таким чином, встановлено, що у джерелах питної води для напування тварин циркулює умовнопатогенна мікрофлора. Відомо, що в умовах порушення умов утримання, годівлі, мікроклімату у тварин та птиці, особливо молодняку, різко знижується резистентність організму. На цьому фоні умовнопатогенна мікрофлора може набувати патогенних властивостей і викликати бактеріальні захворювання. 

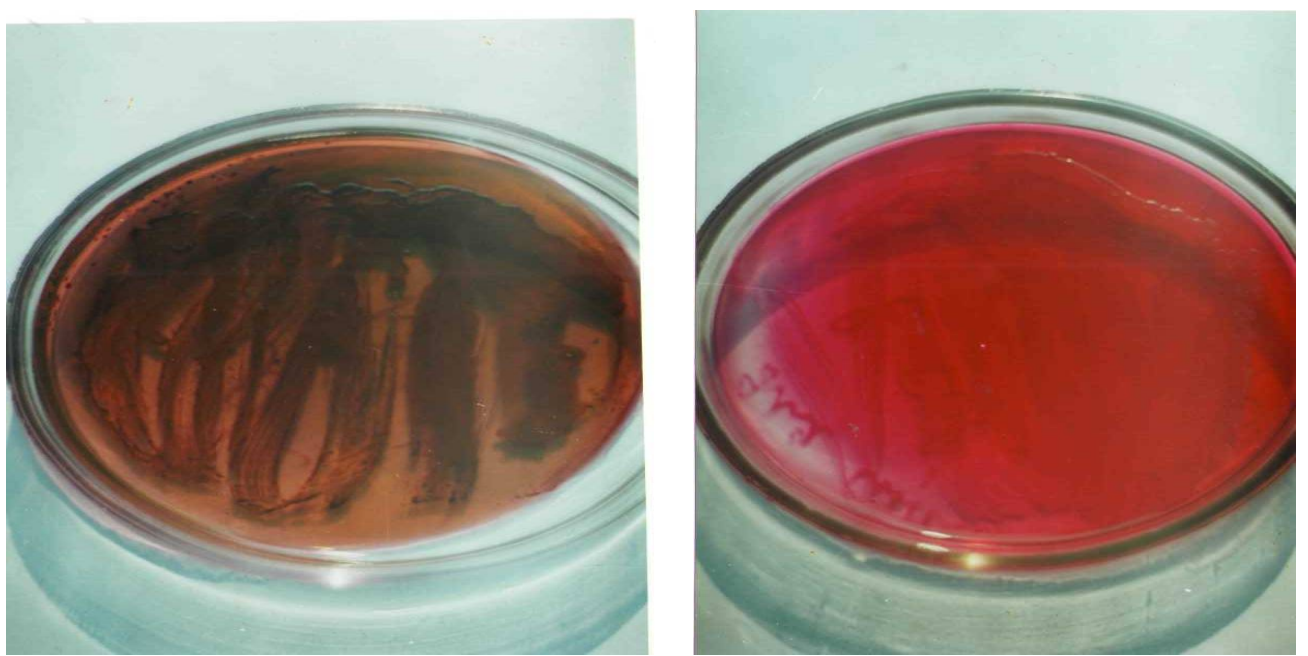

Рис. 1. Облік росту колоній E. coli на середовищі Левіна і Ендо

Із підданих дослідженню проб води виділили 100 культур умовно-патогенної мікрофлори, в тому числі E. faecalis - 32\%, E. coli - 23\%, E. cloacae - 9\%, E. faecium - $11 \%$ і $K$. pneumoniae - 4\%, із них відповідно 59,3; 30,4; 33,3; 54,5 і 75\% були притаманні гемолітичні властивості.

E. faecalis виявили стійкість до еритроміцину, цефуроксиму, бензилпеніциліну, ампіциліну, тетрацикліну, ванкоміцину; E. faecium - до ванкоміцину, ципрофлоксацину, тетрацикліну; представники родини Enterobacteriacea (E. coli, K. pneumoniae, E. cloacae) переважно до амоксициліну, стрептоміцину, левоміцетину.

\section{Висновки}

1. Отже, внаслідок санітарно-мікробіологічної оцінки проб води на тваринницьких підприємствах було виділено умовно-патогенні мікроорганізми: Enterococcus spp., Staphylococcus spp., E. coli, Klebsiella spp., Enterobacter spp., яким були притаманні гемолітичні та антибіотикорезистентні властивості.

2. Дані асоціації мікроорганізмів можуть бути причиною виникнення тяжких форм респіраторних та шлунково-кишкових захворювань у тварин.

Перспективи подальших досліджень. В подальшому планується провести дослідження спрямованих на використання економічно доцільних методів корекції санітарно-мікробіологічних показників води, яка використовується для напування тварин та моніторингу джерел водопостачання на території тваринницьких комплексів, з урахуванням антибіотикорезистентних властивостей умовно-патогенної мікрофлори.

\section{References}

Andrushchuk, I.L. (2015). Chysta voda - osnova zdorovia tvaryn. Zh. Silskyi hospodar, 4-6, 34-36 (in Ukrainian).

Dong, J., Wang, G., Yan, H., Xu, J., \& Zhang, X. (2015). A survey of smart water quality monitoring system.
Environmental Science and Pollution Research, 22(7), 4893-4906. doi: 10.1007/s11356-014-4026-x.

Glasgow, H.B., Burkholder, J.M., Reed, R.E., Lewitus, A.J., \& Kleinman, J.E. (2004) Real-time remote monitoring of water quality: a review of current applications, and advancements in sensor, telemetry, and computing technologies. J Exp Mar Biol Ecol 300(1), 409-448. doi: 10.1016/j.jembe.2004.02.022.

Gómez, J.A.D., Alonso, C.A., \& García, A.A. (2011) Remote sensing as a tool for monitoring water quality parameters for Mediterranean Lakes of European Union water framework directive (WFD) and as a system of surveillance of cyanobacterial harmful algae blooms (SCyanoHABs). Environ Monit Assess, 181(1-4), 317-334. https://link.springer.com/article/10.1007\%2Fs10661010-1831-7.

Helbling, D., \& VanBriesen, J. (2009). Modeling Residual Chlorine Response to a Microbial Contamination Event in Drinking Water Distribution Systems. Journal of Environmental Engineering, 135(10), 918-927. doi: 10.1061/(asce)ee.19437870.0000080 .

Hihiienichni vymohy do vody pytnoi, pryznachenoi dlia spozhyvannia liudynoiu. DSanPiN 2.2.4-171-10: Nakaz MOZ Ukrainy vid 12.05.2012, №400 (zi zminamy vid 15.08.2011) (in Ukrainian).

Hirol, M.M., \& Kovalskyi, V.Ye. (2008). Problemy yakosti vody $\mathrm{v}$ vodoprovidnykh merezhakh. Vodopostachannia ta vodovidve-dennia. Vyrobnychopraktychnyi zhurnal, 2, 1-21 (in Ukrainian).

Holovko, A.M., \& Rublenko, I.O. (2010). Veterynarna sanitarna mikrobiolohiia: navch. posib. K.: Ahrarna osvita (in Ukrainian).

Karas', A.V. (2009). Jekologicheskij monitoring vodoistochnikov i jeffektivnost' ispol'zovanitja uluchshenoj vody $\mathrm{v}$ uslovijah svinovodcheskogo kompleksa: Avtoref. diss. kand. s.-h. nauk. Vitebsk (in Russian).

Laptiev, Yu.O. (2012). Znachennia pytnoi vody u suchasnomu svynarstvi. Efektyvne tvarynnytstvo, 7, 62-64 (in Ukrainian). 
Sokoliuk, V.M., Kozii, V.I., Kozii, N.V., \& Zasiekin, D.A. (2011). Otsinka yakosti vody ta system vodopostachannia u kompleksi preventyvnoi veterynarnoi medytsyny. Suchasne ptakhivnytstvo, 56(102-103), 40-45 (in Ukrainian).

Vajsburd, A.A. (2014). Sanitarno-gigienicheskie trebovanija $\mathrm{k}$ kachestvu vody dlja zhivotnovodcheskih i pticevodcheskih kompleksov. Chast' 1. Harakteristiki kachestva. Naukovo-praktychnyi zhurnal Suchasna veterynarna medytsyna, 3(45), 52-55 (in Russian).

Zapolskyi, A.K. (2005). Vodopostachannia, vodovidvedennia ta yakist vody. Pidruchnyk. K.: Vyshcha shkola (in Ukrainian).

Zasiekin, D.A., Solomon, V.V., Kucheruk, M.D. ta in. (2009). Vplyv nanochastynok sribla na mikrobne zabrudnennia vody. Zdorovia tvaryn i liky, 21, 15 (in Ukrainian). 